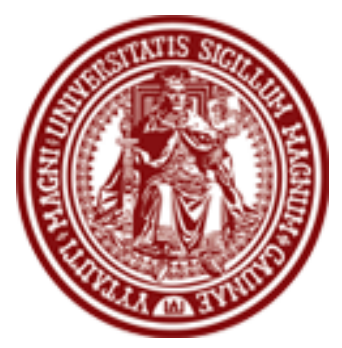

BALTIC JOURNAL OF LAW \& POLITICS

VOLUME 2, NUMBER 1 (2009)

ISSN 2029-0405

http://www.versita.com/science/law/bjlp

Cit.: Baltic Journal of Law \& Politics 2:1 (2009): 97-111

DOI: $10.2478 / \mathrm{v} 10076-009-0006-8$

\title{
JURISDICTION IN INTERNATIONAL MATRIMONIAL MATTERS
}

\author{
JURGITA GRIGIENE் \\ Associate Professor; Dr. \\ Vytautas Magnus University Faculty of Law (Lithuania) \\ Contact information \\ Address: S. Daukanto str. 28, LT-44246 Kaunas, Lithuania \\ Phone: 370-37-327873 \\ E-mail address: j.grigiene@tf.vdu.It
}

Received: April 01, 2009; reviews: 2; accepted: July 21, 2009.

\section{ABSTRACT}

This article analyses the jurisdiction of the court in matrimonial matters. The criteria of jurisdiction, the principal of lis pendens, forum non conveniens, applicable law and the influence of jurisdiction on the outcome of the case are unfolded in the article. Matrimonial law differs from country to country. In some countries there are strict rules; in other countries there are liberal rules for divorce. In different countries there are different criteria for division of joint property between spouses, and different criteria for determining child custody. Depending on which country's court solves matrimonial dispute, there can be different outcomes to a case because each court applies its own conflicts of law rules and determines the applicable law to the lawsuit. This essay explores the peculiarities of international jurisdiction determination rules valid in the European Union, and some worldwide tendencies of international jurisdiction. As the EC Regulation does not determine one basic rule of jurisdiction in matrimonial matters, it is possible to choose from several alternative jurisdiction criteria and start a suit in the courts of several states. The essay addresses cases in which the parties can manipulate and misuse the jurisdiction criteria due to the lis pendens principle, as well as cases in which the legal certainty and legitimate expectation of spouses are infringed upon. The essay also presents particular recommendations about how to improve present legislation by incorporating case transfer mechanism or principles of forum non conveniens. 


\section{KEYWORDS}

International jurisdiction, matrimonial matters, applicable law, lis pendens, forum non conveniens 


\section{INTRODUCTION}

The mobility of persons is rapidly growing. More and more Lithuanians are going abroad to work and live, and vice versa - foreigners are coming to live and work in Lithuania. The growing migration of people increases the amount of international marriages where spouses are nationals of different countries or when the spouses live in a country of which they are not nationals. Regrettably, in many cases marriages do not last until death parts them. When family conflicts are not resolved judicial litigations for divorce, division of property, right of custody and maintenance obligations begin. When the family conflict is across national boundaries additional specific problems occur: which state's court would have jurisdiction for divorce, which state's law should be applied for the litigation or should the judgment of a court be recognized abroad. This article analyses which country's courts are competent to solve family litigation. Criteria of jurisdiction, principal of lis pendens, forum non conveniens, applicable law, and the influence of jurisdiction on the outcome of the case are addressed in the article too. It is very important to establish jurisdiction, because it may determine the whole outcome of the case. The problem of establishing jurisdiction is heterogeneous. On the one hand the competency of judicial institutions is set freely by the state itself; however on the other hand there exist certain principles - substantial contacts of state and dispute, legal predictability, legal certainty, legitimate expectations - which should not be violated when imposing the jurisdiction of courts. Jurisdiction is determined by using various jurisdiction criteria: nationality, domicile, habitual residence, place of marriage (lex loci celebrationis) and others. Nevertheless certain principles exist which should be followed by states when establishing the competence of their courts. Jurisdiction rules should not violate a person's right to a court and the fair trial principle. Considering the significance of jurisdiction rules they are regulated not only by national law but also by unified Regulations of the European Union. The peculiarities of international jurisdiction rules, valid in the European Union, are analyzed in this article. Worldwide tendencies of international jurisdiction are addressed in this article, and law projects (trauvax preparatoires) preliminary documents of the European Union are analyzed as well. The most relevant law issues are revealed by analyzing problems that occur when establishing jurisdiction. In conclusion, recommendations for improving legislation are proposed. 


\section{THE LEGAL FRAMEWORK OF JURISDICTION IN THE EUROPEAN}

\section{UNION}

Family law is related to the traditions and culture of each country. As other fields of law are more and more internationally harmonized, family law remains specific to each country and is dependent upon culture, religion and the traditions of the society. Different attitudes towards the recognition of polygamous marriages or same sex marriages illustrate the variety of family law. Particularities are obvious in all family law fields: the ground of divorce, rules for division of property, recognition of prenuptial agreements, rules for maintenance and rules for child's custody differ. Family law issues were not regulated by instruments of the European Union for a long time. But finally the harmonisation process touched family law in the European Union. European Union law has started to regulate a few separate issues of family law. In 1998 Member states signed the Convention Brussels II (Convention on Jurisdiction and the Recognition and Enforcement of Judgments in Matrimonial Matters). ${ }^{1}$ The signing of convention Brussels II was considered one of the most important achievements of the European Union in family law.

It shows that family law matters are currently regarded as an essential part of European integration and that the Member States, despite considerable divergences in their domestic and international family law, are able to agree on uniform rules dealing with cross-border situations. ${ }^{2}$

European Union legislation moved forward to uniform jurisdiction rules in order to assure free movement of persons within the European Union. Therefore on the 29 of May, 2000, another important step was taken for EU integration when the Councils Regulation (EC) No. 1347/2000 on Jurisdiction and the Recognition and Enforcement of Judgments in Matrimonial Matters and in Matters of Parental Responsibility for Children of Both Spouses was adopted. ${ }^{3}$ This Regulation was replaced by Councils Regulation (EC) Nr. 2201/2003 (further in the article called "Regulation") on the 27 of November, 2003. ${ }^{4}$ The Regulation's scope of practice was extended in cases concerning children. The main advantage of the Regulation, according to V. Vèberaite, is that "parental responsibility is defined widely and the

\footnotetext{
${ }^{1}$ Brussels Convention on Jurisdiction and Recognition and Enforcement of Judgments in Matrimonial matters, Official Journal C 27, 1998.

2 Maarit Jantera-Jareborg, "Marriage Dissolution in an Integrated Europe: The 1998 European Union Convention on Jurisdiction and the Recognition and Enforcement of Judgments in Matrimonial Matters (Brussels II Convention)," Yearbook of Private International Law 1 (1999): 3.

3 Council Regulation (EC) No. $1347 / 2000$ of 29 of May 2000 on Jurisdiction, Recognition and Enforcement of Judgments in Matrimonial Matters and in Matters of Parental Responsibility for Children of Both Spouses, Official Journal L 160/19, 2000.

${ }^{4}$ Council Regulation (EC) No. 2201/2003 of 27 November 2003 on Jurisdiction and the Recognition and the Enforcement of Judgments in Matrimonial Matters and in Matters of Parental Responsibility, replacing Regulation (EC) 1347/2000, Official Journal L 338/1, 2003.
} 
Regulation is not applied only to children of both spouses". ${ }^{5}$ The status of the Regulation meant that the law is directly applied in member states of the European Union. Jurisdiction of family disputes and recognition of judgements are the only institutes of family process law regulated by EU law. Article 1 of the Regulation defines its scope:

This Regulation shall apply, whatever the nature of the court or tribunal, in civil matters relating to: divorce, legal separation or marriage annulment; the attribution, exercise, delegation, restriction or termination of parental responsibility. ${ }^{6}$

The Regulation is applied for divorce; however it does not apply to the grounds of divorce, property consequences and the economical relationships of spouses.

Summarising the situation in European Union law, we conclude that only certain family law issues are uniform in the European Union. Jurisdiction in family cases is the main institute of family law regulated by the uniform rules of European Council Regulation. The issue of applicable law in family disputes is not regulated by European Union law acts and is determined by member states' international private laws rules on conflicts of laws. The uniform rules for jurisdiction is European Union is positively evaluated among scholars. There are prepared proposals by European Commission which goes forth to harmonize other fields of family law, but the proposals are not accepted yet by Member States.

\section{JURISDICTION RULES IN DIVORCE CASES}

Jurisdiction is a very important institute of civil procedure. Until adoption of uniform jurisdictional rules in Europe, each Member State established jurisdiction of international marriages by national legal acts. Depending on culture, legal systems, and traditions, individual countries used different jurisdiction criteria for matrimonial matters. In some countries the main jurisdiction criteria was domicile of spouses; in others it was nationality; in still others it was residence of spouses. The introduction of Regulation unified jurisdiction rules in the European Union. Now litigants are aware that in the entire European Union there are the same rules of jurisdiction. Regulation lists jurisdiction criteria in the Article 3:

In matters relating to divorce, legal separation or marriage annulment, jurisdiction shall lie with the courts of the Member State in whose territory:

\footnotetext{
5 Vigita Vèbraitè, "Scope of Regulation (EC) No. 2201/2003 of 27 November 2003 Concerning Jurisdiction and the Recognition and Enforcement of Judgment in Matrimonial Matters of Parental Responsibility," Teise 63 (2007): 115.

${ }^{6}$ Regulation (EC) No. 2201/2003, supra note 4.
} 
- the spouses are habitually resident, or

- the spouses were last habitually resident, insofar as one of them still resides there, or

- the respondent is habitually resident, or

- in the event of a joint application, either of the spouses are habitually resident, or

- the applicant is habitually resident if he or she resided there for at least a year immediately before the application was made, or

- the applicant is habitually resident if he or she resided there for at least six months immediately before the application was made and is either national of the Member State in question or, in the case of the United Kingdom and Ireland, has his or her "domicile" there. ${ }^{7}$

Competent will be also the court of the nationality of both spouses. ${ }^{8}$ Article 3 also provides that courts of the United Kingdom and Ireland will be competent, if the domicile of spouses is there. "What is required, therefore, is a real link between the parties and the Member State courts which are seized of the proceedings. ${ }^{\prime \prime}$ Regulation establishes seven equal alternative jurisdiction criteria. None of these of criteria has preference. The criteria for jurisdiction are selected according to the link between the parties of the dispute and the state. Even though none of the criteria has preference, the main tendency in the Regulation is clear: the main base for jurisdiction is the habitual residence of the parties. The definition of habitual residence is not provided in the Regulation. Therefore the European Court of Justice has given the descriptions of what the 'residence of persons' means. To acquire domicile or nationality takes a long time, and to acquire residence in a member state it is enough to live in a state more than one year. This is very important to immigrants who frequently change their residence. Even though they do not acquire residence in the new state, they will be treated as a resident of that new state and therefore will have access to courts.

The Regulation is silent on the consequences of dual nationality. There is a case pending at European Court of Justice, where spouses had French and Hungarian nationality. The case is not yet decided by European of Court of Justice, but, as stated in preparatory documents of the court in Advocate General Kokott's opinion,

The court of the Member State in which a judgment was originally given would have had jurisdiction under Article 3(1)(b) of that regulation, it may not regard spouses who both possess the nationality of the Member State of the court

\footnotetext{
${ }^{7}$ Ibid.

${ }^{8}$ Ibid.

${ }^{9}$ Iva Perin Tomičic, "Private International Law Aspects of the Matrimonial Matters in the European Union - Jurisdiction, Recognition and applicable law," Zbornil PFZ 57 (2007): 858.
} 
seized and of the Member State of origin as being exclusively of its own nationality. Rather, it must take into account the fact that the spouses also possess the nationality of the Member State of origin and that the courts of the latter State accordingly would have had jurisdiction in respect of the judgment. For the purposes of determining jurisdiction under Article 3(1)(b) of Regulation No $2201 / 2003$ in the case of spouses who hold more than one nationality, not only the more effective nationality is to be taken into account. The courts of all Member States whose nationality is held by both spouses have jurisdiction under that provision. ${ }^{10}$

This is the recommendation of the Advocate General and we will see whether the European Court of Justice will confirm her opinion and solve jurisdiction in dual nationality cases.

Article 6 of the Regulation provides two cases when the jurisdiction rules are exclusive. When the respondent is a habitual resident in a Member State or is a national of the Member State he can be sued only in accordance to rules set in the Regulation. ${ }^{11}$ In other cases national courts can exercise jurisdiction pursuant to national legislation. If the respondent is a resident or national of a non-European Union country, the court shall avail jurisdiction pursuant to national jurisdiction rules. In Lithuania jurisdiction rules of international divorce are included in the Code of Civil Procedure. The European Court of Justice states that:

Articles 6 and 7 of the Regulation are to be interpreted as meaning that where, in divorce proceedings, a respondent is not habitually resident in a Member State and is not a national of a Member State, the courts of a Member State cannot base their jurisdiction to hear the petition on their national law, if the courts of another Member State have jurisdiction under Article 3 of that Regulation. ${ }^{12}$

So only when no courts of members of states has jurisdiction pursuant to Regulation, the court can avail itself on the basis of national jurisdiction rules.

The court in which proceedings are pending on the basis of Article 3 shall also have jurisdiction to examine a counterclaim, insofar as the latter comes within the scope of this Regulation.

$\ldots$

Without prejudice to Article 3, a court of a Member State that has given a judgment on a legal separation shall also have jurisdiction for converting that judgment into a divorce, if the law of that Member State so provides. ${ }^{13}$

\footnotetext{
${ }^{10}$ I. Hadadi v. C. M. Mesko, European Court of Justice (2008, no. C-168/08).

${ }^{11}$ Regulation (EC) No. 2201/2003, supra note 4.

${ }^{12}$ K. S. Lopez V. M. E. L. Lizazo, European Court of Justice (2007, no. C-68/07).

${ }^{13}$ Regulation (EC) No. 2201/2003, supra note 4.
} 
There is no possibility pursuant to the Regulation for the parties to reach an agreement in which the court will be competent to solve the divorce case.

In summary, it should be noted that the European Union has started to regulate the field of family law. When there were no unified jurisdiction and recognition rules, nationals of the European Union used to encounter difficulties when resolving family disputes. Law acts unifying jurisdiction were passed to guarantee greater legal certainty for the spouses who are aware of European Regulation. The Regulation establishes seven equal, alternative jurisdiction criteria. Spouses have the freedom to choose to which states court to go by selecting alterative criteria. The variety of alternative jurisdiction criteria may lead to forum shopping where litigants can search for a more convenient forum.

\section{PRINCIPLE OF LIS PENDENS}

The Regulation does not set one basic rule of jurisdiction in matrimonial matters. The possibility exists to choose from several alternative jurisdiction criteria and therefore start proceedings in courts of several states. In order to avoid parallel proceedings, the Regulation determined that if a case has already begun in one state the courts of other states do not have the competence to judge that case. Article 16 of the Regulation provides:

A court shall be deemed to be seized, at the time when the document instituting the proceedings or an equivalent document is lodged with the court, provided that the applicant has not subsequently failed to take the steps he was required to take to have service effected on the respondent; or, if the document has to be served before being lodged with the court, at the time when it is received by the authority responsible for service, provided that the applicant has not subsequently failed to take the steps he was required to take to have the document lodged with the court. ${ }^{14}$

Article 17 of the Regulation provides:

Where a court of a Member State is seized of a case over which it has no jurisdiction under this Regulation and over which a court of another Member State has jurisdiction by virtue of this Regulation, it shall declare of its own motion that it has no jurisdiction.

$\cdots$

Where proceedings relating to divorce, legal separation or marriage annulment between the same parties are brought before courts of different Member States,

${ }^{14}$ Ibid. 
the court second seized shall of its own motion stay its proceedings until such time as the jurisdiction of the court first seized is established. ${ }^{15}$

This principal is called lis pendens. However a spouse may in certain circumstances have an incentive to "rush to court" before the other spouse has done so. This may lead to situations where the plaintiff applies for divorce in a particular Member State in order to obtain the application of a particular material divorce law (forum shopping). Lis pendens may have negative consequences for the defendant if it leads to the application of a law with which the defendant is not related. His risk may be illustrated by the following example, presented in the Green Paper:

A Polish couple, married since twenty years, live in Poland with their children. The husband receives an interesting offer to work in Finland for two years. The couple agree that the husband shall accept the offer and that the wife shall stay in Poland. After one year, the husband tells his wife that he wants to divorce. He is aware that divorce proceedings under Polish law are lengthy and that the court must establish that the marriage has broken down completely and irreparably. However, Finnish courts would have jurisdiction under the new Brussels II Regulation, since the husband has lived in Finland for more than one year. Finnish courts apply Finnish law to divorce proceedings according to the principle of lex fori. As a result, the Polish husband can obtain a divorce after six months' consideration period, notwithstanding his wife's objections. Since the husband wants to obtain a divorce as quickly as possible, he seizes a Finnish court immediately, which pronounces the divorce after six months, despite the wife's strong objections. ${ }^{16}$

In international civil process the rule of lis pendens means that the right to commence a lawsuit in one state's court is lost if a lawsuit is commenced in the other state's court. The essential principal of lis pendens is based on the priority of an earlier started case. Naturally an obvious priority of this principal is the simplicity of its definition and rules; on the other hand, it has its own drawbacks: the rules are strict. This conception of lis pendens can often encourage the respondent to make the preventive first action, the so-called "negative acknowledgment, " for the absence of service. ${ }^{17}$

In order to avoid parallel proceedings the principle of lis pendens is incorporated in the Regulation. The principle states that if a spouse started lawsuit

\footnotetext{
15 Ibid.

${ }^{16}$ Commission of the European Communities, "Green Paper on Applicable Law and Jurisdiction in Divorce Matters" // http://eur-lex.europa.eu/LexUriServ/site/en/com/2005/com2005_0082en01.pdf (accessed February 27, 2009).

17 It usually means that the debtor claims a lawsuit against the creditor seeking acknowledgment for him being not indebt that is to deny imaginary obligation, however by doing so in procedural meaning the debtor becomes the plaintiff and formally sets the jurisdiction of a court first.
} 
in one member state, the right to start proceedings in another state is lost. The regulation follows the principle of priority: the one who was first has priority. The regulation does not take into account which court is more related with the case, which member state court has greater connections, where the domicile of parties is, where the marriage endured, and where the property of the spouses is held. Therefore this principle can lead to to an undesirable situation in which the court solving the dispute applies a law which is unrelated.

\section{UNIFICATION OF APPLICABLE LAW}

Material family law differs in each country. There are different essential conditions for marriages. Each society sets a different minimum age for marriage, and different regulations and restrictions on marriage between related persons. The regulation of polygamous marriage or partnership of the same sex varies from country to country. Conditions and basics of divorce also differ in Member States. There are particular rules for the division of matrimonial joint property, or for determining the child's custody in each country. Some legal systems of EU Member States should be mentioned as extremely different examples in regulating the grounds and conditions for divorce:

The Polish Court issues a divorce decree, ruling on whether one of the spouses is responsible for break-up of the marriage, and if so which spouse. ... The grounds for divorce are that a marriage has broken down completely and irrevocably. Both conditions must be obtained. ${ }^{18}$

The grounds for divorce in Ireland are that the spouses have lived apart from one another for a period of, or periods amounting to, at least four years during the previous five years, and that there is no reasonable prospect of reconciliation between the spouses, and that such provision as the court (the Circuit Court concurrently with the High Court - Sec. 38 [1]) considers proper exists or will be made for the spouses and any dependant members of the family. ${ }^{19}$

There is only one kind of divorce in Sweden. It arises irrespective of whether or not the couple are in agreement. Under certain circumstances the divorce must be preceded by a six-month period for reconsideration. A spouse always has the right to obtain a decree for divorce and does not need to rely on any special grounds for such a decree. ${ }^{20}$

\footnotetext{
${ }^{18}$ European Judicial Network in Civil and Commercial Matters (Divorce - Poland)// http://ec.europa.eu/civiljustice/divorce/divorce_pol_en.htm\#1 (accessed February 26, 2009).

${ }^{19}$ European Judicial Network in Civil and Commercial Matters (Divorce - Ireland) // http://ec.europa.eu/civiljustice/divorce/divorce_ire_en.htm (accessed February 26, 2009).

${ }^{20}$ European Judicial Network in Civil and Commercial Matters (Divorce - Sweden)//

http://ec.europa.eu/civiljustice/divorce/divorce_swe_en.htm (accessed February 26, 2009).
} 
In Finland the spouses have the right to divorce after a consideration period of six months from filing the application. Divorce can be granted without the consideration period if the spouses have been separated for the last two years before filing the divorce application. Spouses are not required to list the reason for divorce in the application. When hearing the divorce case, the District Court does not consider the spouses' personal relationship or the reason for divorce. ${ }^{21}$

It can be stated, when summarizing the material law of Member States of European Union, that material basis for divorces differs extremely. Sweden and Finland are examples where conditions of divorce are liberal; there is no need to indicate reason for divorce. Whereas in Poland and Ireland a spouse's guilt must be proven or the spouses have to live separately for four years in order to divorce. Even applying the Regulation, which unifies jurisdiction rules, situations might come up when that court shall apply its own national matrimonial law (lex fori) which may be extremely different from the law spouse's domicile.

One of the ways to avoid application of unrelated material law is the unification of private international law (conflict of law). Rules of private international law determined which country's law shall be applied to the divorce proceedings. If applicable law could be determined by the same criteria (for example residence of spouses) it will not matter in what country the divorce proceedings will be, each member state court will determine and apply law pursuant to the same criteria (for example, residence of parties). Currently, if a divorce proceeding is brought before the courts of a Member State, the applicable law is determined pursuant to the national conflict-of-law rules of that State, which are based on very different criteria.

The majority of Member States determine the applicable law on the basis of a scale of connecting factors by doing so they seek to ensure that the proceeding is governed by the legal order with which it has the closest connection. Other Member States systematically apply their domestic laws (lex fori) to matrimonial proceedings. $^{22}$

There are different opinions, especially between those Member States which apply lex fori and those who apply conflicts of law rules to determine applicable law and apply foreign law within their system. "UK as well as Cyprus, Denmark, Finland, Ireland and Sweden apply the lex fori - hence, once jurisdiction is determined the courts apply domestic rules to a divorce case. ${ }^{23}$ Therefore the EC

${ }^{21}$ European Judicial Network in Civil and Commercial Matters (Divorce - Finland) // http://ec.europa.eu/civiljustice/divorce/divorce_fin_en.htm (accessed February 26, 2009).

22 Proposal for a Council Regulation amending Regulation (EC) No. 2201/2003 as regards jurisdiction and introducing rules concerning applicable law in matrimonial matters, Brussels, 17.7.2006 COM(2006) 399 final 2006/0135 (CNS) (presented by the Commission) \{SEC(2006) 949\}\{SEC(2006) 950\}.

23 James McConalogue and Margarida Vasconcelos, "We Have "Two Speed" Europe for Cross Border Divorce Law," Through the EU Labyrinth (2008) // 
Commission suggested uniform applicable law to matrimonial matter by drafting the proposal Regulation "Rome III". ${ }^{24}$ Project "Rome III" unified applicable law in family matters and does not unify family material law. The Project only sets equal conflicts of rule of law for applicable law. The court that is competent to judge the case according to jurisdiction rules of the Regulation should apply law that is closely connected to the dispute rather than its own state's law (lex fori). Pursuant to the proposal the court could apply the law where both spouses habitual residence was, if one of the spouses still resides there. If unification would be achieved, so in whatever the forum of divorce, the courts of a Member State normally apply the same conflicts of law rules and apply the law which is most closely connected to the case. For example, the previously noted example of the Finish court solving the divorce of a Polish family should apply to the Polish material law. But some Member States did not support the "Rome III" proposal because it would mean great difficulties to apply foreign matrimonial law, and so the proposal was rejected.

Therefore the unification of applicable law in the EU failed and each member state shall now apply either its own rules of conflicts of law or lex fori to matrimonial cases.

\section{THE POSSIBILITY TO TRANSFER THE CASE AND FORUM NON CONVENIENS}

One more alternative to solve the drawbacks of lis pendens and avoid proceeding in non convenient jurisdiction would be to introduce the possibility in Regulation to the transference of a case among courts of Member States. This alternative was presented by the Commission in the Green Paper. The transference of a case to another Member State's court could be envisaged when exclusive circumstances occur and when strict conditions are carried out. ${ }^{25}$ If a spouse applies for divorce in one Member State, the respondent can request the court to transfer the case to another Member State's court, because marriage lasted the longest in that other state. Seeking to guarantee legal certainty, the list of connecting factors could be specified, for example, the common habitual residence of spouses, if one of the spouses lives there, or the common nationality of the spouses. ${ }^{26}$ The possibility to transfer the case could guarantee the legal certainty of the spouses. For example, this would enable the earlier mentioned Polish wife to request a Finnish court for transference of the case to a Polish court, assuming that

http://europeanfoundation.blogspot.com/2008/09/we-have-two-speed-europe-for-cross.html (accessed February 26, 2009)

${ }^{24}$ Council of the European Union, "Press release," $2887^{\text {th }}$ Council meeting, C/08/205.

${ }^{25}$ Commission of the European Communities, "Green Paper," supra note 16.

${ }^{26}$ Ibid. 
both spouses are Polish nationals and Poland being the last common habitual residency of both spouses. "The possibility to transfer a case could provide a remedy to the problems that may arise when one spouse has unilaterally applied for divorce against the will of the other spouse." ${ }^{27}$

Another way that the legal certainty of the spouses could be guaranteed is by introducing the principle of forum non conveniens in the Regulation. The doctrine of forum non conveniens allows a court to use discretionary right and decline to exercise jurisdiction if it is obviously inconvenient to the parties (taking into account the availability of witnesses and other evidences, the possibility of recognizing the decision of the court abroad, applicable law, habitual residence of parties) and if there is another court which could have jurisdiction. EC legislation precluded the application of forum non conveniens. Forum non conveniens doctrine is widely accepted in countries of Common Law system. The doctrine of forum non conveniens is not in incorporated in the Regulation. The jurisprudence of the European Court of Justice confirms that a member state cannot decline jurisdiction on forum non conveniens. But legal thoughts, legal acts and jurisprudence of courts are changing according to the needs of the society. Scalars, the legislator of the European Union and Jurisprudence of European Court of Justice, has the uniform opinion that forum non conveniens shall not be applied in the European Union. With this essay I would like to attract the attention of legal society to this problem and spark discussion about the possibility of introducing forum non conveniens in Regulation. In the previously mentioned example, the Finnish court could decline jurisdiction in the Polish family divorce case because it was inconvenient to both parties. Considering the worldwide tendencies, the right for the court to decline jurisdiction should be established in Regulation. The doctrine of forum non conveniens should be incorporated in Regulation.

Incorporation case transfer or forum non conveniens mechanisms could guarantee better legal certainty for spouses.

\section{CONCLUSIONS}

The jurisdiction in matrimonial matters in the EU is unified by EC Regulation. Seven equal jurisdiction determination criteria are established by the Regulation. Spouses have the possibility to choose in which Member State's court to start proceedings. Material family law is not unified by EU acts and is different in each Member State. Every state regulates conditions and grounds of divorce by its internal law. In some states conditions of divorce are liberal (Finland, Sweden), 
whereas in other states guilt of another spouse has to be proven (Poland) or spouses have to live separately for four years before divorce (Ireland). Conflicts of law rules and determination of applicable law to the matrimonial matters is also not unified in the EU. When a Member State's court starts proceedings, applicable law is determined by that Member State's conflict of law norms, which can lead to the application of lex fori. There were attempts to standardize applicable law for matrimonial matters by Rome III, but the project was not supported by member states. Therefore situations may occur when one spouse starts divorce proceedings in the court of a Member State that applies lex fori for divorce matters. If lex fori drastically differs from the law of habitual residence of another spouse, this could violate the legal expectations and legal certainty of that spouse. Therefore jurisdiction rules in Regulation should be amended by incorporating case transference mechanism, or the doctrine of forum non conveniens. In this scenario, in an exceptional case, the court addressing the case could have possibility to transfer the case to another member with which parties have stronger connections or decline jurisdiction if it is clearly inappropriate to both parties.

\section{BIBLIOGRAPHY}

1. Jantera-Jareborg, Maarit. "Marriage Dissolution in an Integrated Europe: The 1998 European Union Convention on Jurisdiction and the Recognition and Enforcement $f$ Judgments in Matrimonial Matters (Brussels II Convention)." Yearbook of Private International Law 1 (1999): 1-36.

2. McConalogue, James, and Margarida Vasconcelos. "We have "two speed" Europe for cross border divorce law." Through the EU Labyrinth (2008) // http://europeanfoundation.blogspot.com/2008/09/we-have-two-speedeurope-for-cross.html (accessed February 26, 2009).

3. Tomičic, Iva Perin. "Private International Law Aspects of the Matrimonial Matters in the European Union - Jurisdiction, Recognition and applicable law." Zbornil PFZ 57 (2007): 847-880.

4. Vèbraitè, Vigita. "Scope of Regulation (EC) No. 2201/2003 of 27 November 2003 Concerning Jurisdiction and the Recognition and Enforcement of Judgment in Matrimonial Matters of Parental Responsibility." Teisé 63 (2007): 107-115.

\section{LEGAL REFERENCES}

1. Brussels Convention on Jurisdiction and Recognition and Enforcement of Judgments in Matrimonial matters. Official Journal C 27, 1998. 
2. Commission of the European Communities. "Green Paper on Applicable Law and Jurisdiction in Divorce Matters" // http://eurlex.europa.eu/LexUriServ/site/en/com/2005/com2005_0082en01.pdf (accessed February 27, 2009).

3. Council of the European Union. "Press release." $2887^{\text {th }}$ Council meeting, C/08/205.

4. Council Regulation (EC) No. 1347/2000 of 29 of May 2000 on Jurisdiction, Recognition and Enforcement of Judgments in Matrimonial Matters and in Matters of Parental Responsibility for Children of Both Spouses. Official Journal L 160/19, 2000.

5. Council Regulation (EC) No. 2201/2003 of 27 November 2003 on Jurisdiction and the Recognition and the Enforcement of Judgments in Matrimonial Matters and in Matters of Parental Responsibility, replacing Regulation (EC) 1347/2000. Official Journal L 338/1, 2003.

6. European Judicial Network in Civil and Commercial Matters (Divorce - Poland) // http://ec.europa.eu/civiljustice/divorce/divorce_pol_en.htm\#1 (accessed February 26, 2009).

7. European Judicial Network in Civil and Commercial Matters (Divorce - Ireland) // http://ec.europa.eu/civiljustice/divorce/divorce_ire_en.htm (accessed February 26, 2009).

8. European Judicial Network in Civil and Commercial Matters (Divorce Sweden) // http://ec.europa.eu/civiljustice/divorce/divorce_swe_en.htm (accessed February 26, 2009).

9. European Judicial Network in Civil and Commercial Matters (Divorce - Finland) // http://ec.europa.eu/civiljustice/divorce/divorce_fin_en.htm (accessed February 26, 2009).

10. I. Hadadi v. C. M. Mesko (married name Hadadi). European Court of Justice, 2008, no. C-168/08.

11. K. S. Lopez v. M. E. L. Lizazo. European Court of Justice, 2007, no. C-68/07.

12. Proposal for a Council Regulation amending Regulation (EC) No. 2201/2003 as regards jurisdiction and introducing rules concerning applicable law in matrimonial matters. Brussels, 17.7.2006 COM(2006) 399 final 2006/0135 (CNS) (presented by the Commission) $\{\operatorname{SEC}(2006) 949\}\{\operatorname{SEC}(2006) 950\}$. 